\title{
Lusotopie
}

Recherches politiques internationales sur les espaces

issus de l'histoire et de la colonisation portugaises

$\mathrm{XV}(1) \mid 2008$

Indiens du Mozambique et d'Afrique orientale

\section{Vozes asiáticas e o racismo colonial em Moçambique}

Asian voices and the colonial racism in Mozambique

Voix asiatiques et le racisme colonial au Mozambique

\section{Valdemir Zamparoni}

\section{(2) OpenEdition \\ Journals}

Edição electrónica

URL: https://journals.openedition.org/lusotopie/774

ISSN: 1768-3084

\section{Editora}

Idemec - UMR 7307

\section{Edição impressa}

Data de publição: 30 junho 2008

Paginação: 59-75

ISSN: 1257-0273

\section{Refêrencia eletrónica}

Valdemir Zamparoni, «Vozes asiáticas e o racismo colonial em Moçambique», Lusotopie [Online], XV(1) | 2008, posto online no dia 02 fevereiro 2016, consultado o 07 dezembro 2021. URL: http:// journals.openedition.org/lusotopie/774 


\section{VOZES ASIÁTIGAS E O RAGISMO GOLONIAL EM MOÇAMBIQUE}

Evento, estrutura, conjuntura, curta duração, longa duração, micro, macro, específico, total são binômios que, ao menos desde Michelet com o seu Le Peuple e Marx com o seu O Dezoito Brumário mas, sobretudo, desde os Annales, tem acompanhado os historiadores. O presente artigo, embora não explicite, encara estes desafios : tratar do evento, do episódico, dos movimentos da política cotidiana, enfim da curta duração sem esquecer das estruturas, da longa duração: assim o objeto escolhido - a discussão, publicação, desobediência e revogação de leis que prejudicavam os «asiáticos » na então Lourenço Marques - situa-se no âmbito da curta duração - não mais que quatro tumultuados meses de 1913 mas são tratados à luz de fenômeno de longa duração: o racismo que gradativamente ia pautando as práticas sociais na Colónia, tornando-se cada vez mais institucionalizado. Ao mesmo tempo o artigo busca a multivocalidade em presença no debate, ao procurar fazer emergir as raras vozes dos «asiáticos », confrontando-as com os argumentos de colonos e Estado.

\section{Asian voices and the colonial racism in Mozambique}

Event, structure, conjoncture, courte durée, longue durée, micro, macro, specific, total, are opposing terms which have accompanied historians, at least since Michelet and Le Peuple, Marx and The Eighteenth Brumaire of Louis Bonaparte, and above all since the Annales. This paper, althought not referring explicitly to these categories, faces the very challenge they raise: coping with events and episodic movements in everyday politics, in the courte durée, while not overlooking the structures, the longue durée: thus the chosen obj subject - publication of laws harassing "Asians" in former Lourenço Marques, as well as ensuing debates and civil disobedience movements untill eventual revocation - remains within the courte durée - not more than four strained months in the year of 1993 - but are addressed in the lights of a long-standing phenomenon: the increasingly institutionalized racism which came to underlie all social practice within the colony. At the same time, this article tries to show the many voices present to the debate, by highlightening the rare voices of "Asians ", and comparing them with settlers' and State's arguments.

\section{Voix asiatiques et le racisme colonial au Mozambique}

Evénément, structure, conjoncture, courte durée, longue durée, micro, macro, spécifique, total, ce sont des binômes qui, au moins depuis Michelet et son œuvre Le Peuple, ou Marx avec son Dix-huit Brumaire mais, surtout, depuis les Annales, ont accompagné les historiens. Le présent article, bien qu'il ne l'explicite pas, relève ces défis : traiter de l'événement, de l'épisodique, des mouvements de la politique quotidienne, bref de la courte durée sans oublier les structures, la longue durée : ainsi, l'objet choisi - la discussion, la publication, la désobéissance et la révocation des lois qui portaient préjudice aux «Asiatiques» dans l'ancienne Lourenço Marques - se situe dans le cadre de la courte durée - il ne s'agit que de quatre mois tumultueux de 1913 - mais ils sont traités comme un phénomène de longue durée : le racisme qui assujettissait graduellement à certaines règles les pratiques sociales dans la Colonie, devenant de plus en plus institutionnalisé. 
L'article cherche, en même temps, la multiplicité des voix en présence dans le débat, en tâchant de faire émerger les rares voix des "Asiatiques", en les confrontant aux arguments des colons et de l'État.

\section{Nova Iorque, Paris, Lisboa - agosto de 1913}

Depois do sucesso de Tarzan of the Apes lançado em outubro de 1912, The New Story Magazine publicava a terceira parte de The return of Tarzan trazendo na capa o homem-macaco pendurado num galho, entre folhagens pretensamente tropicais. Do outro lado do Atlântico, em Paris, La Mode Pratique : Revue de la Famille publicava várias páginas ilustradas com os mais elegantes modelos femininos para o novo outono que se aproximava. Contudo, o clima político e social não era tão ameno, particularmente na Europa. A sombra da guerra estava se aproximando sorrateiramente sem que, aparentemente, as pessoas se dessem conta. Portugal parecia então estar rumo ao $\operatorname{cas}^{1}$. O ano começara com a posse de Afonso Costa, e alguma esperança. Pouco mais de cem dias depois a crise política voltou à tona e facções republicanas tentaram um golpe. Fora a primeira vez que republicanos atentaram contra um governo republicano. Mau presságio. Logo a seguir, no « 10 de junho » - Dia de Camões - operários clamando por «pão e trabalho » lançaram bombas sobre o cortejo festivo: dois mortos e muitos feridos $(A$ Voz de Árica, 15 de junho de 1913). A possibilidade de que o cronista das ancestrais glórias ultramarinas pudesse ser o elo de união nacional fora, literalmente, explodida.

No começo de Julho o governo retirou o direito de voto dos analfabetos. O sufrágio universal, um dos fundamentos da República, fora suprimido por um governo republicano. A agitação recrudesceu. Tentativas revolucionárias, republicanas e monarquistas se sucederam. Quartéis foram alvos de bombas. Para insuflar combustível na fogueira em que vivia o país, tornou-se pública, mais uma vez, a cobiça alheia sobre suas colônias : foram confirmadas as negociações e, em agosto, rubricado um novo Acordo entre a Grã-Bretanha e a Alemanha que « estabelecia uma nova partilha territorial, assim como alargava os fundamentos da intervenção » por parte das duas potências. O desmembramento e a partilha das colônias portuguesas parecia se tornar uma ameaça cada vez mais real. Era como tentar tomar o pão que alimentava a alma portuguesa. Discursos inflamados, à direita e à esquerda se sucediam, injetando ardor patriótico. Definitivamente 1913 não era um ano tranqüilo para Portugal.

\section{União, Orange, Transvaal - junho de 1913}

A milhares de quilômetros, em Moçambique, e mais ainda em Lourenço Marques, tais atribulações não deixavam de serem acompanhadas com certa inquietação, pois a integridade da colônia dependia da neutralização de tais manobras anglogermânicas. Porém tudo isto parecia estar muito distante. O clima político e social estava em maior ebulição bem mais perto, logo ao lado, na recém criada União Sul-Africana. O motivo nevrálgico era a nova legislação acerca da imigração que atingia frontalmente a larga comunidade indiana.

${ }^{1}$ As informações abaixo foram coletadas em <www.arqnet.pt/portal/portugal/grandeguerra/ pgm1910.html>, acessada em 14 de abril de 2003 . 
Não que fosse novidade. Cada uma das quatro províncias que, em 1910, passaram a integrar a União já tinha leis restritivas à imigração e aos direitos de residência para os asiáticos ${ }^{2}$. Em sucessiva e cada vez mais restritiva legislação (1876, 1890, 1891) o Orange Free State, africânder, dificultava a presença de indianos tendo mesmo proibido que árabes, chineses, coolies ou qualquer outro asiático ou coloured person pudesse ter negócios ou terras em seu território. Na República Sul-Africana (Transvaal), a legislação de 1885, inaugurara longa lista de restrições aos indianos. Mas tal política de caráter racial não era apanágio dos boers como podemos ser tentados a pensar de maneira anacrônica. Também as colônias austrais da liberal Grã-Bretanha tinham legislação restritiva. A província do Natal, que fora pioneira em receber indianos, passou em 1895 a impor, sob pena de prisão e deportação, uma taxa de £. 3 àqueles que não se recontratavam. O Immigrants Restriction Act de 1897 (e suas emendas de 1900, 1903 e 1906) impuseram critérios de educação, saúde, idade e posses para os indianos (exceto para os coolies) que pretendessem entrar na Província. A medida visava e conseguiu coibir o fluxo de migrantes indianos livres. Em 1902 foi a vez da colônia do Cabo editar o seu Immigration Act para limitar a entrada de asiáticos ${ }^{3}$.

Toda esta legislação restritiva, porém, não era acatada sem questionamentos e resistência. Nomes como Gandhi, Quinn e Naidoo lideraram, a partir de 1907, um movimento pregando a resistência passiva, particularmente forte no Transvaal que, em 1908, levou ao desafio aberto à legislação comercial, à queima pública de registros e passes ${ }^{4}$. O governo do Transvaal reagiu : multou, prendeu, confiscou mercadorias e deportou maciçamente indianos. Alguns chegaram mesmo a autoimolar em protesto. A própria formação da União foi percebida pelos líderes indianos como um perigo à comunidade uma vez que, doravante, a Inglaterra já não poderia intervir diretamente em disputas envolvendo os indianos em terras do novo país.

Esta oposição contudo, não impediu que três anos depois da formação da União fosse implantado o Immigrants Regulation Act, que consolidou a política nacional racista. Todos os imigrantes não brancos foram afetados, inclusive a população negra sul-africana uma vez que, o Ato de 1913, não só manteve como reforçou as barreiras internas para a movimentação dos negros sul-africanos que, a partir de então, passaram a serem legalmente definidos como cidadãos de segunda classe, sem direitos de livre movimento, sujeitos à mesma legislação e restrições impostas aos estrangeiros ${ }^{5}$.

\footnotetext{
${ }^{2}$ Para uma detalhada cronologia da legislação ver <www.sahistory.org.za/ pages/mainframe. htm>, acessada em 30 de março de 2004.

${ }^{3}$ Ver entre outros J. Pereira LeIte, Em torno da presença indiana em Moçambique - séc. XIX e primeiras décadas da época colonial, Comunicação apresentada ao IV Congresso Luso-Afro-Brasileiro de Ciências Sociais, Rio de Janeiro, IFCS/UFRJ, 2-5 de setembro de 1996 e W. Beinart e S. Dubow (eds), Segregation and Apartheid in Twenty-Century South Africa, Londres, Routledge, 1995 ; B. Freund, Insiders and Outsiders: The Indian Working Class of Durban, 1910-1990, Portsmouth, Heinemann / Londres, James Currey / Pietermaritzburg, University of Natal Press, 1995.

${ }^{4}<$ http://scnc.udw.ac.za/doc/texts/kc/kctext2.html>, acessado em 15 de abril de 2003.

${ }_{5}^{5}$ S. Peberdy, «A Brief History of South African Immigration Policy, <www.polity.org.za/ html/govdocs/green_papers/migration/histsa.html>, acessada em 15 de abril de 2003.
} 
Entretanto a nova legislação acabou por injetar ânimo no movimento de oposição e teve a capacidade de unir segmentos sociais distintos : os comerciantes, os trabalhadores indentured e ex-indentured ${ }^{*}$, os mais pobres e todos os demais, atingidos pela nova lei que não reconhecia a legitimidade dos casamentos religiosos islâmicos e hinduístas. Em novembro de 1913, milhares de homens, mulheres e crianças, liderados por Gandhi, marcharam em desafio à lei.

\section{Lourenço Marques - agosto de 1913}

Enquanto Portugal e a União ferviam, a cidade parecia estar mergulhada na bonança. Na imprensa, raras referências à situação vivida na Europa e mesmo a do território vizinho. Embora pelo interior a fome fosse avassaladora, os colonos brancos pouco sentiam seu efeito e $O$ Incondicional informava que a Casa ABC tinha «bilhetes postaes ilustrados, artigos de fantasia, de perfumaria, gramofones e discos além de lembranças de Lourenço Marques »; o «Varietá - Theatro e Cinematographo» apresentava todas as noites «explêndidos e sensacionais programas $»^{6}$.

A vida parecia escorrer para um mar de tranqüilidade. Nada disto, contudo, durou muito. Em junho já havia burburinho nas rodas masculinas formadas nos cafés, bars e praças ${ }^{7}$. O motivo não poderia parecer mais prosaico : um regulamento para o horário de funcionamento do comércio, discutido há meses, fora finalmente aprovado pelo Conselho do Governo em princípios de agosto, conforme noticiava o Lourenço Marques Guardian ${ }^{8}$. O que parecia mais um ato meramente administrativo e burocrático provocou, como veremos, forte celeuma envolvendo a comunidade asiática da cidade. Mas, afinal, o que se pretendeu com tal Regulamento?

Segundo se dizia, o comércio em Lourenço Marques era caótico não tendo horas para abrir ou fechar; os caixeiros trabalhavam entre 14 e 16 horas diárias, com pouco descanso semanal. A cidade tinha «sido até hoje o paraíso do explorador do empregado $»^{9}$. A reclamação principal, contudo, recaía sobre os monhés. Contra eles se uniam dois tipos de reclamantes: os seus empregados diziam ser submetidos a hardships and long hours e os comerciantes brancos denunciavam a concorrência desleal ${ }^{10}$. Mas antes de discutir as relações mantidas entre os colonos e os monhés, vamos ao que preconizava o Regulamento : estabelecia que o dia normal de trabalho seria dividido em dois períodos: das 7 às 12 e das 14 às 19 horas. Entretanto, excluía alguns tipos de estabelecimentos tais como padarias, talhos, farmácias, casas de comidas - quer para europeus, quer para indígenas -, restaurantes, peixeiros, floristas, vendedores de hortaliças, vendedores de frutas, hotéis, bares, escritórios do comércio e indústria, bancos, casas bancárias ou de

* Nota da redação : indentured, contratados.

6 O Incondicional (OI), 10 de julho e 7 de agosto de 1913.

7 OI, 26 de junho de 1913.

${ }^{8}$ Lourenço Marques Guardian (LMG), 14 de agosto de 1913. O Lourenço Marques Guardian era ligado aos capitais ingleses investidos na cidade e que controlavam as companhias monopolistas de Água e Luz. Cf. O Africano (OA), 19 de setembro de 1912.

$9 \quad L M G, 18$ de agosto de 1913.

${ }^{10} L M G, 24$ de julho de 1913 ; OA, 23 de julho de 1913. 
câmbios e ainda os barbeiros, cabeleireiros, vendedores de jornais e livreiros instalados na estação do caminho de ferro, além das casas de chá e tabacarias. Todos os demais estabelecimentos deveriam permanecer fechados nos feriados oficiais, no dia de descanso semanal e, o que causou grande polêmica, nas quartas-feiras, a partir do meio-dia. A medida atingia mais particularmente a parcela islâmica dos asiáticos já que muitos deles respeitavam o dia sagrado das orações e fechavam as lojas ao menos no período vespertino das sextas-feiras. Com o novo Regulamento deveriam permanecer abertos neste dia e fechar num dia da semana que nada lhes dizia. Vale lembrar que disposições também se aplicavam aos ambulantes, em sua imensa maioria, mulheres africanas.

Fixava a semana máxima em 55 horas de trabalho, divididas em seis dias, e jornadas de seis horas consecutivas devendo ter ao meio-dia um intervalo não inferior a duas horas para a refeição. Entretanto, os patrões podiam prolongar as horas sem remuneração adicional. Mal foi aprovado e já circularam as críticas. Mas desta vez não se tratava apenas dos costumeiros «protestos » formais. Os atingidos partiram para a organização e desrespeito aberto ao novo Regulamento. Sob o título «Cantineiros e Monhés - Viva a Liberdade!», o Lourenço Marques Guardian, denunciava a «sem cerimônia com que meia dúzia de monhés e cantineiros » resolveram rejeitar o horário de encerramentos das lojas e, em tom irônico, dizia que os cantineiros deveriam reivindicar que seus estabelecimentos permanecessem abertos enquanto «os pretos tiverem sede» e fechar somente quando tivessem "gasto a massa toda »; que os empregados deveriam ser «obrigados a trabalhar enquanto tiverem vida e saúde $»^{11}$.

Por seu turno a Associação dos Logistas [sic], que contava com 130 sócios, reuniu uma Assembléia Geral para apreciar o Regulamento e convidou todos os comerciantes e industriais da cidade, mesmo os não sócios. Dos 38 comerciantes presentes, 25 eram indianos e chineses e a maioria dos restantes eram cantineiros europeus ${ }^{12}$. Decidiram rejeitar, "por altamente prejudicial aos interesses do comércio retalhista », o encerramento na hora do almoço e mesmo o horário de abertura e fechamento. Foi nomeada uma comissão para pedir a sustação e emenda do Regulamento, mas no dia seguinte, sábado, no mesmo dia em que a comissão avistou-se com o Juiz da Relação Augusto Ferreira dos Santos, então Governador Geral Interino, o Regulamento foi publicado no Boletim Oficial. Era uma punhalada pelas costas, mas não mortal e a reação não tardaria.

É de se destacar que nenhum indiano ou chinês integrou a comissão. Nesta sociedade colonial marcada por crescente divisão racial, certamente os comerciantes brancos se sentiam mais capacitados e autorizados a falar em nome de todos e, por seu turno, não é improvável que os asiáticos estivessem conscientes do fato que os brancos, ainda que cantineiros, reuniam um certo capital simbólico derivado da cor de sua pele e que não por acaso coincidia com a do Governador Geral.

Esta assembléia, onde predominara «o monhé e o china», foi considerada « uma vergonha » pelo $O$ Incondicional ${ }^{13}$, que não podia admitir que « o parasitismo de alguns ignorantes » pretendesse representar o comércio laurentino. Aliás, dizia o jornal :

${ }^{11} L M G, 28$ de agosto de 1913.

12 Ibid.

${ }^{13}$ OI, 28 de agosto de 1913. 
«Custa-nos muito dar o título de comerciante a qualquer saberête que, com quatro latas de sardinha e uma ancoreta do tal já refinado, arrasta o pobre negro ao vício, à miséria e ao hospital. Vivendo maritalmente com uma negra que explora e prostitui, o herói de pangol é a vergonha de nossa civilização e comércio. »

O Conselho do Governo se reuniu para ouvir as reclamações dos « retalhistas e cantineiros europeus e índios e dos barbeiros da cidade e subúrbios ». À sessão compareceu «desusado número de pessoas, na sua maioria negociantes indianos e cantineiros ${ }^{14}$ e, "pela primeira vez tão intensamente se manifestavam essas Castas e essas Classes ${ }^{15}$ que, porém, só puderam se expressar através de advogados. Um representou a " classe indiana », outro, os demais « retalhistas », o que indica que apesar de juntos no movimento havia uma linha racial mais profunda que separava cantineiros brancos e asiáticos e os impedia de terem um único advogado. A atuação do advogado dos asiáticos foi assim comentada:

«Elegante, bem fallante, patrocinava a causa dos comerciantes asiáticos a quem Lourenço Marques deve o que é, e que não é de forma alguma essa parasitagem com que os patriotas continuam a temperar as suas objurgatórias quando os negociantes vão mal... [...] o asiático, tem as suas relações comerciaes com as chamadas classes baixas que tem o dia tomado e que só depois das 7 costuma fazer suas compras - Negociam em 'panos'. Nada têm com o comércio do vinho colonial, com as chamadas cantinas - Quanto à chamarem a colônia asiática, parasitaria, é fácil provar que as duas ruas principaes de Lourenço Marques foram edificadas por asiáticos. Tem a colônia aqui milhões de Libras em propriedades. ${ }^{16}$

Como o Conselho não estava nada disposto a rever sua recente decisão foi criada nova comissão ${ }^{17}$. Por precaução, os reclamantes começaram a angariar assinaturas para um telegrama de protesto a ser enviado a Lisboa a fim de questionar o Conselho. Dizia-se que em Lisboa se faria « eco das gemebundas lamurias dos cantineiros de Lourenço Marques », principalmente por parte dos influentes exportadores do vinho colonial. O Africano afirmava: «Querem [os cantineiros] à fina força fechar e abrir os seus estabelecimentos quando muito bem lhes der na 'gana' para continuar, sem interrupção, o envenenamento da raça negra! ${ }^{18}$. Pressionado, o Conselho decidiu introduzir algumas modificações mas o Governador Geral vetou e manteve o texto original ${ }^{19}$.

A resposta foi imediata : lock out! No sábado, 6 de setembro, percorreu, de boca a ouvido, o boato e na segunda, eclodiu no Mercado Municipal o inédito movimento que se tornou um acontecimento excepcional que abalou a pasmaceira da

${ }_{14} L M G, 25$ de agosto de 1913.

15 OA, 21 de agosto de 1913.

${ }^{16} O A, 21$ de agosto de 1913. Na realidade os comerciantes indianos, muçulmanos ou não, também comerciavam com vinhos e em algumas circunscrições do interior eram predominantes. Ver V. Zamparoni, «Monhés, Baneanes, Chinas e Afro-maometanos: colonialismo e racismo em Lourenço Marques, Moçambique, 1890-1940 », in M. CAHEN et alii (eds), Lusophonies asiatiques, Asiatiques em lusophonies, Paris, Karthala, 2000, VII : 191-222.

${ }^{17} L M G, 25$ de agosto de 1913.

$18 O A, 6$ de setembro de 1913.

${ }^{19} L M G, 8$ de setembro de 1913. 
rotina local. Toda a manhã « esteve muita gente em frente do Bazar a ver os acontecimentos ». Não mais que uma dúzia de lojas, incluindo «três das principais mercearias, as mais importantes casas de moda, relojoarias e livrarias » abriram suas portas, todo o comércio restante aderiu ${ }^{20}$.

Diante da situação, a direção da Associação dos Empregados do Comércio, buscando boicotar a ação dos patrões, se comprometeu «a fornecer todas as requisições de géneros » que lhe fosse solicitada. O Estado, por seu turno, agiu rápido, improvisando um talho municipal e conseguiu «por outros processos » assegurar o abastecimento de pão. A Associação dos Proprietários, que representava o grande comércio, resolveu apoiar o Regulamento, mostrando um claro divisor de classe ao não deixar margem para que seus interesses fossem confundidos com a arraia miúda dos cantineiros.

O movimento conseguiu paralisar o comércio da cidade por um dia e meio e dele participaram «cantineiros, merceeiros, monhés, chineses e até [...] meia dúzia de comerciantes extrangeiros $»^{21}$. Mas o comércio local não era só levado adiante por estes. Teriam as barmaids, brancas, que dirigiam os afamados bars onde se bebia champanhe e onde se podia desfrutar da companhia de «deusas » brancas, aderido ao protesto e privado seus clientes brancos ricos de tais delícias ${ }^{22}$ ? Não há qualquer referência sobre a participação feminina exceto pela notícia de que, acusada de «perturbar a ordem pública », a esposa do dono de uma « casa de comida » - o nome dela não foi mencionado pela fonte mas o dele sim - « acompanhada de grande multidão, foi remetida para o tribunal, mas, [não] se provando a acusação, foi absolvida $»^{23}$. Ausentes também estão as referências aos ambulantes, cuja maioria era composta por homens e mulheres africanos. Teriam aderido ao boicote e privado seus clientes brancos do conforto de receber à porta de casa o carvão e as verduras frescas ? Ao reunir cantineiros asiáticos e brancos e ao ter o apoio de parcela de comerciantes brancos e mesmo de estrangeiros, o movimento ainda que timidamente ultrapassou as barreiras raciais e de classe mas e as de gênero? Nada sabemos.

O movimento foi suspenso após um telegrama do ministro das Colônias ter sido interpretado como sendo favorável aos reclamantes ${ }^{24}$. A situação, contudo, não havia sido resolvida. No final de outubro, o Governador Geral cedeu e considerou oportuno por em execução as emendas aprovadas pelo Conselho e que, ao serem por ele vetadas, tinham ocasionado o lock out. Venciam os reclamantes. Mas o que tudo isto significou? António Ennes e o Pe. Daniel da Cruz, com toda a crueza, resumiam qual o lugar ocupado pelos asiáticos no imaginário colonial : sórdidos, astutos, degenerados, mesquinhos, lânguidos, efeminados, repelentes, etc. ${ }^{25}$ Palavras duras, mas que não impediam Ennes de se opor à sua

20 Ibid.

${ }^{21} L M G, 11$ de setembro de 1913.

${ }^{22}$ V. Zamparoni, "Copos e Corpos: a disciplinarização do prazer em terras coloniais », Travessias - Revista de Ciências Sociais e Humanas em Língua Portuguesa, 4/5, Lisboa, 2004 : $119-137$.

$23 L M G, 8$ de setembro de 1913.

${ }^{24} L M G, 11$ de setembro de 1913.

${ }^{25}$ Ver a opinião de Ennes, Gruz e outros colonos em Zamparoni, «Monhés, Baneanes, Chinas...", op. cit. 
expulsão, pois, dizia ele, tal comunidade, nenhum favor pedia ao Estado e davalhe grande arrecadação alfandegária, além de ser, em sua opinião, pacífica, obediente, que não mendigava, e estava praticamente ausente dos registros policiais e, sobretudo, era apolítica. Ora, contrariamente ao que julgava Ennes, não é difícil pensar que esta movimentação de cantineiros e merceeiros, cuja maioria era formada por asiáticos fosse a expressão local das táticas de resistência passiva amplamente praticada entre a comunidade indiana da vizinha União.

Não podemos desconsiderar o fato de que a pequena comunidade indiana laurentina, com suas clivagens religiosas, de classe, casta e origem, mantinha estreitos laços de parentesco e solidariedade com suas congêneres além fronteira. Era inclusive acusada por isto ${ }^{26}$. Se havia associação de interesses comerciais e familiares, não haveria também uma circulação de idéias e táticas políticas? Difícil acreditar que a pregação de destacados líderes indianos, Gandhi entre eles, ficasse circunscrita às fronteiras físicas uma vez que esta comunidade era vista essencialmente como trans-nacional. A lição do Transvaal não deixou de ser mencionada pelo Lourenço Marques Guardian ${ }^{27}$. É possível que, minoritária em Lourenço Marques, não tivesse força organizativa própria como mostravam ter seus vizinhos, e que, portanto, tivesse que buscar aliados com maior capital simbólico diante do meio colonial local. Sua ativa participação neste movimento de resistência aos ditames administrativos, que interessavam sobretudo aos colonos, revela que embora fossem pacíficos, não eram apolíticos e lutavam para ter seus direitos - ainda que contestados - assegurados.

\section{Lourenço Marques - outubro de 1913}

Mal terminava uma crise na qual os asiáticos estavam envolvidos, começava outra. Em princípios de outubro de 1913 o Conselho de Governo, à semelhança da vizinha União Sul-Africana, voltou a discutir um regulamento para a entrada de asiáticos $^{28}$. Nem todos os colonos porém concordavam com tal regulamentação. Numa alocução considerada brilhante pelo Guardian - opinião que soa a ironia Dr. Egas Moniz Coelho (representante de Inhambane) disse que tal ato seria um «verdadeiro atentado à economia da Província ». Segundo o jornal ele fez «apologia » da importância dos asiáticos no Natal e na Província e recomendou a leitura das opiniões de Sá da Bandeira, Andrade Corvo e António Ennes, afirmando

26 Ver G. de Azevedo, Relatório sobre os trabalhos do recenseamento da população de Lourenço Marques e Subúrbios, referido ao dia 1 de dezembro de 1912, Boletim Oficial, 1912, suplemento: 177-193 e Zamparoni, «Monhés, Baneanes, Chinas...», op. cit.

2711 de setembro de 1913.

28 É longa a legislação voltada para controlar a entrada de asiáticos na Colônia: Portaria Provincial (PP) n 46 de 26 de janeiro de 1899 publicada no Boletim Official (BO) no 4 de 1899 , revogada pela $P P$ no 439 de 9 de agosto de 1900, $B O$ no 32/1900 e restabelecida pela PP n 596 de 20 de novembro de 1900, no $B O$ n 47/1900; Nota da Administração Civil de Lourenço Marques, de 10 de dezembro de 1907, publicada no $B O$ no 50/1908, retificada nos BO 30/1909 e BO 40/1909; PP no 871 de 18 de julho de 1912 publicada no BO no 29/1912. Ver a respeito, Zamparoni, «Monhés, Baneanes, Chinas...», op. cit. 
que não se devia atender à « orientação ou desorientação das maiorias locais, mas sim ao interesse coletivo $»^{29}$.

No mesmo dia em que noticiava a retomada das discussões da «complexa e delicadíssima questão da imigração asiática », o Guardian tomou para si o encargo de « esclarecer» a opinião pública laurentina acerca dos «métodos que os próprios índios se serv[iam] para obter trabalhadores do seu país». Afirmava que além dos comerciantes - «homens possuídos de capital e com interesses ligados a esta terra », havia a grande massa da «colônia asiática », constituída por humildes trabalhadores empregados nos estabelecimentos urbanos ou do interior e por operários - pedreiros, carpinteiros, etc., que nunca tiveram as vinte libras, ou trezentas rúpias, que eram exigidas aos emigrantes. Passou em seguir a descrever o processo de recrutamento que se fazia na Índia, particularmente nos distritos de Kathiawar e Diu, cuja população pobre aceitava qualquer proposta para conseguir trabalho na costa oriental da África. Bombaim (Mumbay), era o centro de recrutamento, de onde partia a maior parte dos empregados nas lojas dos asiáticos de Lourenço Marques ${ }^{30}$.

Estes trabalhadores eram contratados, em geral, pelo prazo de três anos com o salário anual de 100 rúpias, ou seja, $30 \$ 31$. A passagem que custava $£$. 5 era paga pelo patrão que também fornecia casa, comida e vestuário aos seus empregados durante a vigência do contrato. Segundo afirmava o Guardian, os salários eram inferiores aos pagos aos indígenas, que em Lourenço Marques ganhavam em média 10 \$ por mês. Segundo o jornal estes «pacientes e industriosos trabalhadores » aceitavam passar alguns anos «sofrendo até inclemências » para adquirir a experiência e poupar umas quinze libras das vinte que recebiam ao fim do contrato. Com isto tinham a possibilidade de se estabelecerem por conta própria ou em sociedade em «qualquer ponto distante da província » uma vez que fossem «benquistos dos compatriotas » que lhes forneceriam stock mercadorias para iniciar o negócio. Julgava, o jornal, que mesmo como proprietários não teriam significativa melhoria de vida, entre outras coisas porque não tinham vida familiar pois nunca traziam as suas mulheres e concluía : «a vida destes pobres negociantes do interior é talvez inferior a dos indígenas, que ao menos têm diante de si a oportunidade de melhorarem a sua condição aproveitando-se da instrução que gratuitamente lhes é ministrada $»^{32}$. Vida familiar, para o articulista, só se constituía com mulheres da própria origem. Além disso a conclusão soa como uma perfeita desfaçatez pois era de todos conhecido que, exceto a ação das missões, em sua maioria protestantes, na verdade não havia educação ou mesmo «instrução » digna deste nome acessível aos indígenas nem na capital e muito menos no interior ${ }^{33}$.

${ }^{29} L M G, 9$ de outubro de 1913.

${ }^{30} L M G, 9$ de outubro de 1913.

${ }^{31}$ Embora em 22 de maio de 1911, o «monarquista » Réis (Rs.) tenha sido substituído pelo republicano Escudo (Esc.), valendo este mil réis, continuou corrente o uso da nomenclatura da moeda antiga.

${ }^{32} L M G, 9$ de outubro de 1913.

${ }^{33}$ Ver V. Zamparoni, «Deus branco, almas negras : colonialismo, educação, religião e racismo em Moçambique, 1910-1940", in Lusofonia em África: História, Democracia e Integração Africana, Maputo, Codesria, 2005, disponível em <www.codesria.org/Links/Research/luso/zamparoni. pdf $>$, acessado em 10 de outubro de 2006 . 
Embora concordasse que a interiorização do comércio era resultante do esforço destes homens « pioneiros de certo valor fazendo uma obra que nem aos imigrantes portugueses de mais humilde condição decerto se recomendava », concluía que « considerando a estampa de gente que negoceia no interior, a maneira por que vivem e os laços frágeis em extremo, que os ligam a esta Colónia, é uma questão a discutir se Moçambique não teria passado melhor sem eles » e que, portanto, não se devia «abrir as portas da Província para enchê-la de gente deste calibre ». Para justificar sua proposta toma como exemplo a vizinha colônia do Natal : desde 1870 estava « habitada por gente branca » com suas mulheres e filhos ; que construíra lojas e se dedicara um pouco à agricultura. Vivia em paz. Mas tal paz fora quebrada com «a invasão de 'Abubacar' e dos seus numerosos 'irmãos', apoiados por estas casas de comércio em atacado de Durban» que rapidamente estendeu por toda a Colônia uma rede de lojas cujos proprietários, em razão da «vida frugalíssima » que levavam, faziam uma concorrência difícil de combater, o que teria levado à extinção o «negociante branco » e o assenhoreamento do comércio pelos asiáticos. Tal situação danosa, segundo o jornal, também se repetia na África oriental inglesa, em detrimento dos colonos ingleses, onde até mesmo circulava a « moeda índia » ${ }^{34}$. A convicção na superioridade racial dos brancos e a idealização de sua hegemonia no meio colonial obscurecia o fato de que os asiáticos eram os melhores e mais eficazes agentes da difusão das mercadorias ocidentais e, com elas, indiretamente, das idéias e formas de vida europeias junto às populações do interior.

O Guardian lamentava ainda que os anteriores Governadores de Moçambique não tinham lançado «os alicerces duma colônia branca nesta região » e que Portugal cometera o mesmo «gravíssimo erro " que os ingleses ao permitir que « uma raça improdutiva e parasitária desapossasse os conquistadores e colonos originais ». Isto tudo se deu, segundo o jornal, pelo fato de que ambas « sacrificaram os seus brancos e os próprios pretos em troca dum pequeno proveito imediato como sucedeu com os plantadores de assucar (sic) no Natal, que nas páginas da história hão de ficar como sendo os originadores da perturbação asiática do Natal ». Julgava que em Moçambique «o problema asiático » já era «suficientemente grave » de modo que não era conveniente permitir a «entrada de negociantes, que aqui estão apenas de passagem e cujo único fito é disporem de suas fazendas pelo mais alto preço que lhes for possível obter » e que além do mais era preciso considerar o «aviltamento da raça negra e ao aumento dos mulatos, demasiado numerosos já, se Moçambique rialmente (sic) aspira a ser uma colônia de gente branca! ». Afirma ainda que até mesmo as «duas classes de índianos » - empregados e patrões - residentes em Lourenço Marques, seriam contrárias « à política da porta aberta ». Os primeiros temeriam que seus ordenados se reduzissem ainda mais e os segundos, a concorrência. Por fim, lembrou a situação vivenciada na União e particularmente no Transvaal por causa desta mesma questão ${ }^{35}$.

Duas semanas depois, o Guardian noticiou que o Conselho do Governo havia votado o novo Regulamento segundo o qual os «imigrantes naturais da Ásia e equiparados » seriam doravante obrigados a pagar $£ .8$ anuais nos primeiros três

${ }^{34} L M G, 9$ de outubro de 1913

35 Ibid. 
anos de residência nesta província e £. 1 anual nos anos seguintes, ficando também obrigados a fornecerem a sua fotografia e impressões digitais às autoridades. Os asiáticos já residentes pagariam £. 1 por $\mathrm{ano}^{36}$. A semelhança entre a lei moçambicana e a aprovada na União, o alto valor cobrado em terras portuguesas e a forma como foi recebida não passou despercebida. Em pequena nota, em inglês, o Guardian comentou que a taxa bem menor (£. 3) na vizinha África do Sul tinha suscitado protestos por meio de uma "'active' passive resistance ", enquanto que em Moçambique, o governo tinha passado tal provisão sem "the slightest likelihood of a protest, active or otherwise " $^{37}$.

\section{Lourenço Marques - novembro de 1913}

Finalmente, no começo deste mês o Boletim Oficial publicou o novo «Regulamento para a polícia e fiscalização da entrada de asiáticos e equiparados nos territórios da Província de Moçambique sob a directa administração do Estado ${ }^{38}$. Numa curiosa cartografia colonial o novo édito passou a considerar como asiáticos ou equiparados a estes todos os indivíduos naturais da Ásia ou da África ao norte de Cabo Delgado ou a leste da costa de Moçambique, qualquer que fosse a sua nacionalidade, e cujos «usos e costumes » divergissem dos do «povo europeu». Aqui, não gratuitamente a raça foi substituída pelo «povo ». A entrada dos asiáticos em Moçambique só seria admitida por via marítima, pelos portos de Moçambique, Angoche, Quelimane, Chinde, Inhambane, e Lourenço Marques e pela via terrestre, pelas estações do caminho de ferro fronteiriças ou pelos pontos em que houvesse um representante da autoridade colonial.

Os asiáticos estrangeiros e mesmo os «nacionais » (ou seja, os chamados indoportugueses, sobretudo goeses) residentes em colônias estrangeiras, que pretendessem entrar na Província deveriam, antes de tudo, requerer uma licença à autoridade administrativa do conselho em que desejassem desembarcar e munidos dela, juntamente com uma prova que demonstrasse « estar isento de culpa e não ter cumprido qualquer pena por crime a que corresponda pena maior », solicitar ao consulado de Portugal um bilhete de identidade, no qual constaria o nome, naturalidade, filiação, idade, profissão, última residência, sinais característicos, além de trazer uma fotografia do portador, exceto se fosse do sexo feminino, e as impressões dos polegares direito e esquerdo. Se a autoridade sanitária não pusesse «justo impedimento » ao desembarque, tal documento seria entregue à autoridade portuária com uma quantia em ouro suficiente para garantir a passagem de volta ${ }^{39}$.

Os que provassem ter como destino autorizado o Transvaal, estariam isentos das exigências indicadas, mas ficariam sujeitos ao imposto sanitário. As mulheres estariam sujeitas às mesmas regras e os filhos menores até 15 anos, quando em companhia dos pais, estariam isentos das taxas e licenças. As exceções de aplicavam

${ }^{36} L M G, 27$ de outubro 1913.

${ }^{37} L M G, 6$ de novembro de 1913.

${ }^{38}$ Portaria Provincial 1379 de 29 de outubro de 1913, publicada no $B O$ no 44, de 1 novembro de 1913 e Telegrama do Ministro das Colónias, de 26 de dezembro de 1913, publicado no $B O \mathrm{n}^{\mathbf{0}}$ 52/1913.

${ }^{39} L M G, 6$ de novembro de 1913. 
somente aos asiáticos que fossem funcionários do Estado e aos empregados das autoridades consulares. Se, por ventura, a autoridade sanitária julgasse que determinado individuo apresentasse risco à saúde pública o mesmo seria internado no Lazareto e, além das taxas de desembarque e depósito de garantia, deveria pagar $1 \$ 000$ réis por dia de internamento, valor que seria recolhido pela Repartição de Saúde do Porto antes mesmo do desembarque.

Uma vez na colônia, era preciso obter uma licença de residência, para a qual se deveria pagar $36 \$ 000$ réis em ouro por ano. Os já residentes que obter um bilhete de identificação passado pela autoridade administrativa do local onde residiam e pagar uma taxa anual de $4 \$ 500$ réis em ouro. Quem fosse pego sem a licença seria preso como desobediente e depois de cumprir a pena imposta pelo poder judiciário seria expulso caso não obtivesse a licença de residência. Mesmo depois de tamanha burocracia e controle, não estava assegurada a livre movimentação senão entre as circunscrições e conselhos de um mesmo Distrito.

Avesso aos asiáticos e partilhando as teses racistas em voga, o Lourenço Marques Guardian passou a publicar pequenas notas que direta ou indiretamente ajudavam a piorar a imagem já combalida da comunidade junto ao meio colonial. Por exemplo, informava o público, em tom de denúncia, que pelo interior afora os monhés faziam a escrituração em sua própria língua o que permitia « toda ordem » de trapaças fiscais. Depois noticiou as gestões que se faziam nos Estados Unidos para limitar a entrada de orientais ${ }^{40}$. Não contente, dedicou extenso editorial para tratar dos asiáticos na África do Sul no qual incluiu reflexões pertinentes a Moçambique.

Segundo o jornal, o progresso moroso de Angola e Moçambique era o motivo pelo qual estas colônias ainda não tinham enfrentado uma « questão indiana » nos moldes daquela que constituía o «pesadelo» da África do Sul e outras possessões inglesas, entretanto, Moçambique, ciente do que se passava ao lado, pusera « as barbas de molho » e promulgara o Regulamento para restringir a imigração « dessa gente ». O editorial é claro:

« Não pode deixar de nos interessar o que se está passando na Índia e no Natal e nós estamos naturalmente ao lado das colónias inglesas que desejam pôr uma barreira à invasão dos 'coolies'. As pretensões absurdas desta gente parecem ser ilimitadas. A sua última reivindicação consiste em afirmar que os índios devem gosar nas outras colónias inglesas de todos os direitos de cidadão, pretensão esta que tem merecido o apoio de muitas pessoas cuja bondade e absoluta sinceridade estão na razão directa da sua leviandade e ignorância. $»^{41}$

Para sustentar a sua tese, afirmava que em razão do sistema de castas que « traçam acentuadas linhas de divisão entre as várias classes da mesma raça » eles não têm a «noção de direitos de cidadão como nós, os ocidentais » e que a isto se somavam as divisões religiosas entre muçulmanos e hinduístas, concluindo portanto que a Índia nunca poderia ser governada democraticamente e que lá os coolies não gozavam de nenhum direito, sendo considerados como uma « classe de criaturas inferiores e à parte ». Reconhecia que o « índiano » importado não deixava de ter seus préstimos, mas se os «descendentes dos conquistadores que pacificaram

${ }^{40} L M G, 11$ e 15 de dezembro de 1913.

${ }^{41} L M G, 18$ de dezembro de 1913. 
o Hindustão não desejarem abandonar o lugar que ocupam no mundo, indispensável será que mantenham bem nítida, como os seus antepassados fizeram, a distinção entre os direitos do súbdito e os direitos do cidadão » e às colônias assistiria o «direito de se libertarem, querendo, do perigo asiático que as ameaça $»^{42}$.

Até agora apontei a opinião do Estado e dos colonos - ou ao menos de parcela deles - acerca da multifacetada comunidade asiática, porém, para se compreender a delicada trama com que se tece a história, em particular a colonial, é preciso olhar o contexto a partir de distintos ângulos e para isto não basta uma leitura à contrapelo da documentação colonial. Dentro das raras possibilidades oferecidas pelos documentos é preciso fazer um esforço para ouvir as vozes que, submersas, parecem á primeira vista nunca terem sido pronunciadas. Assim compreender o racismo, a discriminação e a opressão imposta aos asiáticos nos conduz a perguntar também o que pensavam estes acerca de tais preconceitos e dos colonos? Não são fartas as fontes para tal estudo. A imprensa local era em sua maioria controlada por colonos brancos e mesmo a imprensa negra e mestiça (no caso $O$ Africano e o $O$ Brado Africano) não raro partilhavam da opinião daquela. Uma fonte rica, sem dúvida, seria a correspondência privada de membros desta comunidade discriminada, que, entretanto não tenho conhecimento de que exista, ao menos nos arquivos moçambicanos.

Discretos por excelência, diante do clima social hostil, os membros desta comunidade reagiam de forma indireta, como mostramos acima, e raramente expressavam suas opiniões em público. Talvez esta tenha sido uma estratégia de resistência oculta sob o manto do silêncio. Apesar disto é possível garimpar das páginas dos periódicos alguns exemplos de contra-argumentos ao racismo que envolvia a comunidade colonial. Neste polêmico e agitado ano de 1913, somente dois artigos reivindicados por asiáticos foram encontrados na imprensa consultada. Um em $O$ Africano e outro no Guardian que, como vimos, dedicou dezenas de páginas a criticar os indianos. O primeiro deles foi publicado por este último periódico, em inglês, em sua edição de 20 de outubro de 1913. O jornal alertou que, a pedido do autor, estava publicando a carta tal qual havia chegado até eles, o que nos permite pensar que não a editaram para adequá-la aos seus ditames. De fato o autor, Sikandar Pauras, termina a carta com o postscriptum: "I do not wish slightest change be made in the original text and I take upon my selves [sic] the responsibility for same". Vejamos do que se tratava.

Embora não tenha mencionado, tratava-se de uma resposta ao artigo «A população asiática ", publicado pelo mesmo Guardian na edição de 9 de outubro, acima comentado. A carta, em inglês, estava escrita na segunda pessoa do plural o que indica que o autor era indiano e se sentiu atingido pela publicação do artigo. Começou por dizer que o diretor do jornal não deveria censurar os indianos por venderem barato pois os nativos morreriam de fome se tivessem que pagar os altos preços praticados pelos comerciantes europeus. Defendia o direito de mandar trazer jovens aprendizes, pois, como em qualquer lado, os velhos experientes pediriam salários altos. Protestou contra a acusação feita pelo jornal de que eles estariam degradando a colônia ao incrementar a mestiçagem afirmando : 
«Você escreveu que não trazemos nossas famílias para cá e que somos os responsáveis pelo aumento dos mestiços [half-castes] - naturalmente não há nada a recriminar quanto a isto porque nenhum homem do mundo deve ficar sem uma parceira do sexo oposto por um largo tempo e o Governo proibiu-nos de ir a casas de mulheres públicas brancas - então são as nativas que estão á nossa disposição - todavia se o Governo deseja que não haja celibatários, nem mestiços e ninguém sem esposa, seria aconselhável editar uma lei para este efeito; há muitos de meus irmãos que tem suas esposas aqui, mas o Governo achou necessário fazer inquirições para a identificação destas mulheres como se elas fossem esposas de outras pessoas e não daquelas com quem vieram. ${ }^{43}$

Mais claro impossível : a mestiçagem era explicada como resultante da política governamental que vedava o acesso dos asiáticos aos prostíbulos brancos, dificultava a imigração das mulheres indianas e até mesmo se imiscuía na privacidade familiar com intuitos de identificação. Estes motivos que alegadamente levavam os homens indianos a se associarem às mulheres africanas locais não são suficientes contudo para explicar a formação de half-castes já que não consideram o que motivava as mulheres locais a se associarem aos mesmos e a deles terem filhos.

O segundo artigo foi publicado na edição de 6 de dezembro de 1913 de O Africano, sob o título «Os asiáticos ». Seu autor, Omar Khan, era súdito britânico. Era também uma resposta a um artigo - «Arrazoados», de F. Sarmento publicado em $O$ Incondicional. Neste artigo, o primeiro que o jornal publicou, neste ano de 1913, acerca dos asiáticos, Sarmento fez uma série de comentários racis$\operatorname{tas}^{44}$. Khan reagiu afirmando que tais ataques feriam «a dignidade e os interesses da classe mahometana desta cidade » e por isso, na qualidade de membro, « embora obscuro d'aquela classe » pedia para $O$ Africano publicar «alguns reparos » àquele "Arrazoado ». Começou por contestar a tese de que na Província não havia assunto mais importante do que o regulamento de entrada dos asiáticos, perguntando se temas como o "melhoramento dos portos, a viação, a agricultura etc. » que deveriam «arrancar à miséria os indígenas », o tratado secreto anglo-alemão, a adesão da temida Espanha à Tríplice Entente, que como vimos ameaçava a independência de Portugal, a « humilhante cláusula da sentença de MacMahon », perderiam, por ventura, o interesse diante do «espectro dos asiáticos »?

« Se os homens se calarem, as pedras da cidade se encarregarão de responder », disse poeticamente o autor, face à insistente afirmação de que os monhés não traziam benefício à Província. Bastaria recorrer à Repartição de Fazenda para se constatar que os monhés tinham investido na colônia mais capital que a soma de todos os negociantes portugueses e estrangeiros. Afirmou que se os asiáticos fossem embora com seus capitais, o custo de vida na cidade e interior duplicaria e « o indígena, cujo bem estar deve estar acima de todos e de tudo, ficará privado dos confortos da civilização exceptuando os que resultam dos vinhos de Portugal ». Diante da queixa de que os monhés não davam empregos aos trabalhadores brancos, argumentou dizendo que a «humanidade » da Província não se limitava à população branca e concluiu : «Os brancos podem ir e vir, mas os pretos podem ficar. E ai de quem não entender assim num terrível dia de retribuição ». Por

\footnotetext{
${ }^{43} L M G, 20$ de outubro de 1913

${ }^{44}$ OI, 6 de novembro 1913.
} 
isso os negociantes monhés não discriminavam: vendiam «os seus artigos mais baratos que os negociantes europeus tanto aos brancos como aos pretos». $\mathrm{O}$ acerto de contas insinuado na resposta não tinha como ser mais premonitório, ainda que quando os brancos se foram os monhés não tenham ficado tão bem assim. Mas esta é outra história.

Diante da pergunta de Sarmento se o Brasil tinha precisado de asiáticos para se « desenvolver e ocupar o lugar proeminente que chegou no comércio mundial », respondeu de maneira contundente: «Não senhor, o Brazil não careceu de asiáticos, do mesmo modo como o mundo avançado não careceu de portuguezes ». Não bastasse esta chicotada no orgulho português, tocou mais uma vez na ferida quando afirmou que Sarmento «trahe a alma nacional de querer viver, não na história, mas da história », pois embora admirasse o curto período em que Portugal tinha passado pela história como um «meteoro brilhante » era preciso não se fazer de cego e reconhecer a verdade dos fatos : o Brasil devia a Portugal a descoberta e não a prosperidade.

E não ficou por aí. Diante da acusação de que os asiáticos constituíam uma « raça inferior e parasitária », Khan lembrou que o «sangue sarraceno », mesmo cristianizado, ainda corria em Portugal. De qualquer modo considerava «inútil entrar em polêmicas irritantes com argumentos odiosos de raças e crenças » por isto não lhe interessava apreciar as «invectivas raciais» de Sarmento. A respeito da «moralidade comercial dos asiáticos » afirmou que se os monhés recorriam ao crédito era porque eram homens honrados e citou o exemplo uma empresa « européia » laurentina que também recorria ao crédito, inclusive de asiáticos pois ao falir «abotoou-se com £. 32 000, só dos indianos ». Diante da também constante crítica à frugalidade e mesquinhez dos monhés, Khan retrucou ao afirmar que não via vantagens em «comer, beber e gozar bem » no presente e depois « ver nossas filhas deixarem se raptar pelo primeiro seductor, por não terem meios por uma união lícita que satisfaça as exigências da natureza, e nossos filhos suicidarem-se por iguais motivos ».

Sarmento atribuía o atraso da Província à «gangrena » que a corroia, ou seja, ao «asiático improgressivo e conservador » e Khan, de forma irônica, perguntou se seriam os asiáticos os causadores da gangrena " 'di lá' da metrópole » [sic] e das demais colônias portuguesas. Para Khan a prosperidade da Província estaria assegurada se houvesse a facilitação da entrada e extensão aos asiáticos dos mesmos direitos garantidos aos demais estrangeiros: bastava que o governo desse « segurança da vida », pronta e imparcial "justiça acessível a todos », livre curso à agricultura, tratasse da saúde pública, castigasse o vício e premiasse a virtude que «boa comida, bela bebida, rico vestuário, moradas luxuosas e outros confortos, virão como conseqüência natural ». Conhecedor do meio empresarial local não hesitou em afirmar que sem os capitais asiáticos todo o comércio iria parar as mãos de europeus estrangeiros e não de portugueses de modo que ficaria prejudicada tanto a metrópole quanto a colônia.

\section{Goa - dezembro de 1913}

Como era de se esperar o que ocorria em Lourenço Marques não podia deixar de repercutir na Índia. Em Goa (Margão), O Ultramar publicou correspondência 
enviada de Moçambique que classificava o Regulamento de asiáticos como subversivo a todas as doutrinas liberais e um atentado aos direitos civis previstos na Constituição. Segundo o jornal o Regulamento tratava os «asiáticos como que fossem saltimbancos ou maltrapilhos de perigoso contacto, e os sujeita a vexames que affrontam o seu brio », notadamente a exigência de serem fotografados. Isto era especialmente humilhante pois naquela época os direitos de cidadania ainda não se haviam dobrado aos mais mesquinhos interesses do estado e tais operações de identificação eram restritas ao âmbito policial e aos criminosos ${ }^{45}$.

O autor afirmava que foi o espírito de imitação do que faziam « os vizinhos » que levara à edição de semelhante lei sem «tomar na linha de conta o facto que o asiático representa um factor importante da vida económica da Província e é um dos melhores elementos para a civilisação do indígena do sertão ${ }^{46}$. A situação vivida na vizinha União e a resistência passiva levada a cabo por Gandhi, somente referenciada de leve na imprensa laurentina foi aqui evidenciada. O correspondente não só historiou como alertou para o fato de que os acontecimentos do Transvaal deveriam servir de aviso para o governo sobre a «borrasca » que ameaçava Moçambique pois embora situação vivida nesta colônia não fosse igual àquela, era «difícil prever qual a táctica que os asiáticos nacionaes adoptarão para reagirem contra a lei ${ }^{47}$. Na edição seguinte o mesmo jornal com base em nova correspondência de Lourenço Marques, afirmou que já se ouvia que « os asiáticos portuguezes, coadjuvados por asiáticos estrangeiros », iriam iniciar em Lourenço Marques «o movimento de resistência passiva a exemplo dos seus compatriotas na colónia vizinha $»^{48}$. Se houve, esta articulação não transpareceu. De qualquer modo, como mencionamos, mesmo que não tenha sido formalizada qualquer aliança política, é inequívoca a circulação de idéias no espaço local, regional e mesmo transcontinental entre os membros da comunidade.

A comunidade asiática indo-britânica, de Lourenço Marques, enviou um extenso memorial a Pherozeshah Mehta pedindo sua intervenção junto ao Governo português pela extinção do Regulamento. Estava implícita a ameaça já avançada pelas autoridades inglesas de que se isto não ocorresse, os indo-portugueses também teriam tratamento discriminatório nos territórios britânicos, o que, segundo se noticiava, ainda não ocorria. Diante deste perigo o Grémio Portuguez de Bombaim foi ao cônsul português desta cidade expor os inconvenientes de tal Regulamento e a União Goana fez um grande comício de protesto ${ }^{49}$.

O ano de 1913 chegara ao fim e com ele o famoso Regulamento. A limitação de sua aplicação aos territórios diretamente administrados pelo Estado excluindo as áreas controladas pelas Companhias Majestáticas, particularmente a $\mathrm{C}^{\mathrm{ia}} \mathrm{de}$ Moçambique, de capitais ingleses, visava contornar os protestos das autoridades britânicas, mas este cuidado não bastou e, por telegrama de 26 de dezembro, o Ministro das Colónias ordenou sua suspensão por quatro meses, para melhor

\footnotetext{
45 O Ultramar (OU), 15 de dezembro de 1913 e 2 de março de 1914.

${ }^{46}$ OU, 15 de dezembro de 1913.

47 Ibid.

${ }^{48}$ OU, 2 de março de 1914.

${ }^{49}$ OU, 13 de julho de 1913 e 2 de março de 1914.
} 
avaliação ${ }^{50}$. A polêmica em torno da presença asiática, entretanto, não chegaria ao fim e tampouco os colonos deixariam de ver a comunidade asiática com menoscabo, mas esta é uma longa história. Como vimos, tanto pela presença nas movimentações contrárias à regulamentação dos horários comerciais quanto nas duas cartas, os «asiáticos » - hinduístas, muçulmanos e mesmo cristãos - embora desprezados pelos colonos como uma « raça inferior », não se mantinham passíveis diante do racismo circundante. Não me parece, pois que pudessem ser, como queria Ennes, considerados apolíticos. Os protestos publicados na imprensa laurentina e goesa expressam com limpidez a clara compreensão que tinham das questões coloniais mais amplas, perscrutando, inclusive a contraditória alma lusitana.

Outubro de 2006

Valdemir ZAMPARONI

Universidade Federal da Bahia (Brasil)

Centro de Estudos Afro-Orientais zampa@ufba.br.

${ }^{50} L M G, 29$ de dezembro de 1913. 